\title{
Community knowledge and the role of health extension workers on integrated diseases among households in East Hararghe Zone, Ethiopia
}

This article was published in the following Dove Press journal:

Risk Management and Healthcare Policy

I July 2016

Number of times this article has been viewed

\author{
Ayichew Seyoum' \\ Kedir Urgessa' \\ Tesfaye Gobena ${ }^{2}$ \\ 'Department of Medical Laboratory \\ Sciences, ${ }^{2}$ Department of \\ Environmental Health Sciences, \\ College of Health and Medical \\ Sciences, Haramaya University, Harar, \\ Ethiopia
}

Background: Ethiopia constitutes approximately 1\% of the world's population but it contributes to $7 \%$ of the world's HIV/AIDS cases. Malaria is the most important disease of humans in terms of mortality, morbidity, and long-term effects upon quality of life, especially in Ethiopia. Despite the ongoing efforts and progress in fighting HIV/AIDS and malaria, these diseases remain the leading cause of morbidity and mortality in the country. In this study, we assessed community knowledge and the role of health extension workers on integrated diseases among households in East Hararghe Zone, Ethiopia.

Methods: A community-based multistage stratified cross-sectional study was conducted from February to March 2014 among six woredas of the East Hararghe Zone, Ethiopia. The data were collected from 2,319 households using structured questionnaires. A total of 12 well trained data collectors conducted a face-to-face interview with the head female of each household. The data entered on Epi-Data version 3 were then exported for analysis on STATA version 11.

Results: Multivariable logistic regression showed that among the 1,967 (92.7\%) study participants who scored above the mean value in regard to the overall knowledge of HIV/AIDS, study participants who could read/write (adjusted odd ratios $[\mathrm{AOR}]=2.54,95 \%$ confidence interval $[\mathrm{CI}]: 1.15-5.61, P=0.021$ ) and worked as a daily laborer (AOR $=0.40,95 \% \mathrm{CI}: 0.17-0.91$, $P=0.029$ ) were significantly associated with comprehensive knowledge about HIV/AIDS. Meanwhile, out of the 2,172 eligible study participants for the malaria interview, 934 (43\%) scored above the mean in regard to the overall knowledge about malaria. Rural residents ( $A O R=0.27$, 95\% CI: $0.17-0.44, P<0.005$ ), $>45$ years of age (AOR $=1.44,95 \% \mathrm{CI}: 1.04-1.99, P=0.030$ ), and single marital status $(\mathrm{AOR}=3.81,95 \% \mathrm{CI}: 1.97-7.37, P<0.005)$ were significantly associated with comprehensive knowledge about malaria.

Conclusion: Based on the findings of this study, health extension workers' number of monthly regular visits of each household was high, with the overall knowledge of study participants regarding malaria was unsatisfactory, unlike the overall knowledge of study participants regarding HIV/AIDS, which is very high.

Keywords: HIV/AIDS, malaria, health extension workers, knowledge

\section{Background}

Globally, an estimated 35.3 million people were living with HIV at the end of 2012; of these, 2.1 million were adolescents aged 10-19 years, of which the majorities were girls $(56 \%)$. The majority of HIV infections are in sub-Saharan Africa, where $85 \%$ of all adolescents living with HIV were located in 2012 (1.7 million). Approximately 1.3 million adolescents living with HIV in sub-Saharan Africa were in Eastern and
Correspondence: Ayichew Seyoum College of Health and Medical Sciences, Haramaya University, PO Box 235, Harar, Ethiopia

Tel +25I 259|| 003879

Fax +25I 2525666808 I

Email ayichewseyoum@gmail.com 
Southern Africa and 390,000 in the West and Central Africa. Outside sub-Saharan Africa, South Asia had the highest number of adolescents living with HIV $(130,000)$, accounting for $6 \%$ of the global burden of HIV among adolescents, followed by East Asia and the Pacific (110,000); Latin America and the Caribbean (81,000); Eastern Europe and Central Asia (22,000); and the Middle East and North Africa (17,000). ${ }^{1}$

According to the latest World Health Organization estimates released in December 2015, there were 214 million cases of malaria in 2015 and 438,000 deaths. Sub-Saharan Africa continues to carry a disproportionately high share of the global malaria burden. In 2015, the region was home to $88 \%$ of malaria cases and $90 \%$ of malaria deaths. Some 15 countries - mainly in sub-Saharan Africa - account for $80 \%$ of malaria cases and $78 \%$ of deaths globally. In areas with a high transmission of malaria, children $<5$ years are particularly susceptible to infection, illness, and death; more than twothirds $(70 \%)$ of all malaria deaths occur in this age group. ${ }^{2}$

The substantial investment in the health sector in terms of human resources, construction of facilities, equipping, and providing pharmaceuticals will definitely impact positively on the health status of the nation. In 2003, in response to the country's health problem, the Ethiopian Federal Ministry of Health launched a new health care plan, the "Accelerated Expansion of Primary Health Coverage" through a comprehensive Health Extension Program (HEP). Health extension workers (HEWs) are young female who took a 1-year course of skill-oriented basic training on HEP packages. HEWs' major task is to increase knowledge and skills of communities and households in order to deal with preventable diseases and be able to efficiently utilize services available at the nearby health institutions. ${ }^{3,4}$

In Ethiopia, for many decades, HIV/AIDS and malaria have been recognized as major public health problems, however, the current knowledge on HIV/AIDS and malaria is not sufficient, even after the launch of HEP. This is because of limited access to information, low level of comprehensive knowledge, and widespread misconceptions about HIV/AIDS and malaria, which could be barriers in the use of intervention techniques. ${ }^{5-7}$

A better understanding about the barriers to HEP and community's knowledge about HIV/AIDS and malaria is important for identifying effective strategies to improve the community's knowledge about HIV/AIDS and malaria. Therefore, this study assessed the knowledge of the study participants and the role of HEWs toward providing knowledge of HIV/AIDS and malaria.

\section{Materials and methods}

Study area and period

A community-based cross-sectional study was carried out from February to March 2014 on randomly selected households residing in selected six woredas of the East Hararghe Zone. East Hararghe Zone is among the 20 zones in Oromia Regional state, Ethiopia. According to current political structure, the zone has 19 woredas/districts.

\section{Study population and data collection}

A total of 2,343 households were included in the study. The sample size was large enough to assess the knowledge levels of the respondents on both malaria and HIV/AIDS. The study participants were selected using a multistage stratified simple random sampling technique. Among 19 woredas of East Hararghe Zone, six woredas were selected using a simple random sampling technique. Then, kebeles of the woredas were stratified into urban and rural kebeles, and two kebeles (the smallest administrative unit) were randomly selected from each randomly selected woreda. Finally, the study participants were proportionally allocated to each kebele based on the household's size.

Study participants were the female head of each household who met the eligibility criteria (aged over 18-years, able to speak and hear at the time of the interview, and were not critically ill) and who volunteered to participate. Data were collected by a face-to-face interview with the female head of each household. A total of 12 well trained individuals who had completed high school were the data collectors and three experienced senior Public Health professionals were involved in field supervision. The questionnaire was adopted from the Malaria Indicator Survey and other similar studies. ${ }^{20}$ The questionnaire had questions related to sociodemographic characteristics, knowledge about HIV/AIDS and malaria, as well as the roles of HEWs. The knowledge levels of the participants were measured based on their overall knowledge level about malaria and HIV/AIDS. Accordingly, those who scored above the mean value were considered as knowledgeable, while those below the mean as less knowledgeable.

\section{Ethical consideration}

The study protocol was reviewed and approved by Haramaya University, College of Health and Medical Sciences Institutional Health Research Ethics Review Committee. Written informed consent was obtained from all study participants, and confidentiality was kept during and after the data collection. 


\section{Data processing and analysis}

Data were entered to EpiData Version 3.1 (Odense, Denmark) and exported into Stata Version 11.0 (Stata Corp. Ltd., College Station, Texas, USA) for data processing and analysis. The data was then analyzed using appropriate descriptive and bivariate statistical tests, such as proportion, mean, crude odds ratio, and Pearson's chi-square tests. Finally, a multivariate logistic regression model was used to determine predictors of the outcome and control of confounding variables. Both the crude odds ratio and adjusted odds ratio (AORs) were reported with its $95 \%$ confidence interval (CI), and $P$-value $\leq 0.05$ was considered as the cutoff point for statistical significance for all statistical tests. The overall knowledge about HIV/AIDS and malaria, and the role of HEWs toward the knowledge of the respondents were assessed using a scoring system. A score of 1 was given to correct responses, 0 being used for incorrect/ do not know responses. Mean value was used to categorize study participants into two categories. A score less than the mean value was considered as low knowledge, while a score greater than the mean value was considered as high knowledge.

\section{Results}

\section{Sociodemographic characteristics of the study participants}

Out of the calculated 2,343 sample size for the study, 2,319 study participants were interviewed regarding HIV/AIDS which gave a $99 \%$ response rate. Meanwhile, out of the calculated 2,343 sample size for the study, 2,172 study participants were interviewed about malaria with a $92.7 \%$ response rate (Table 1).

\section{Knowledge and practice of study participants regarding HIVIAIDS}

Among 2,319 study participants who meet the eligibility criteria, the majority $(91.5 \%)$ of the study participants reported that they have heard about HIV/AIDS before the study period. However, the proportion of urban study participants who had heard about HIV/AIDS was significantly higher than that of the rural study participants $\left(98.8 \%\right.$ vs $90.2 \%, \chi^{2}=27.2861$, $P<0.005)$. Among the 2,121 study participants who had heard about HIV/AIDS, the majority (73.3\%) of the study participants mentioned HEWs as a source of information about HIV/ AIDS. Although, the proportion of rural study participants who mentioned HEWs as a source of information about HIV/AIDS was significantly higher than that of urban study participants ( $77 \%$ vs $\left.53.7 \%, \chi^{2}=77.2541, P<0.005\right)$ (Table 2 ).
Table I Sociodemographic characteristics of study participants among the households from six woredas of East Hararghe Zone, February to March 2014

\begin{tabular}{|c|c|c|c|}
\hline Variable & Category & Number & Percent \\
\hline \multirow[t]{6}{*}{ Study participant woreda } & Gursum & 370 & 15.9 \\
\hline & Babile & 226 & 9.8 \\
\hline & Kurfacele & 140 & 6.1 \\
\hline & Kombolcha & 336 & 14.5 \\
\hline & Metta & 613 & 26.4 \\
\hline & Haramaya & 634 & 27.3 \\
\hline \multirow[t]{3}{*}{ Age, years } & $18-30$ & $\mathrm{I}, 044$ & 45 \\
\hline & $31-45$ & 804 & 34.7 \\
\hline & $>45$ & 471 & 20.3 \\
\hline \multirow[t]{2}{*}{ Residence } & Urban & 337 & 14.5 \\
\hline & Rural & 1,982 & 85.5 \\
\hline \multirow{3}{*}{$\begin{array}{l}\text { Number of household } \\
\text { members }\end{array}$} & $\leq 2$ & 179 & 7.7 \\
\hline & $3-5$ & 1,123 & 48.4 \\
\hline & $>5$ & 1,017 & 43.9 \\
\hline \multirow[t]{3}{*}{ Religion } & Christian & 291 & 12.5 \\
\hline & Muslim & 2,024 & 87.3 \\
\hline & Other & 4 & 0.2 \\
\hline \multirow[t]{4}{*}{ Marital status } & Married & 2,036 & 87.8 \\
\hline & Single & 115 & 5.0 \\
\hline & Divorced & 106 & 4.6 \\
\hline & Separated & 61 & 2.6 \\
\hline Educational status of the & Illiterate & I,657 & 71.4 \\
\hline \multirow[t]{6}{*}{ respondents } & Read/write & 152 & 6.6 \\
\hline & Ist-4th Grade & 167 & 7.2 \\
\hline & 5th-8th Grade & 196 & 8.5 \\
\hline & 9th-10th Grade & 110 & 4.7 \\
\hline & IIth-12th Grade & 4 & 0.2 \\
\hline & $>12$ th Grade & 33 & 1.4 \\
\hline \multirow[t]{5}{*}{ Occupation of respondent } & Farmer & $\mathrm{I}, 487$ & 64.1 \\
\hline & Daily laborer & 217 & 9.4 \\
\hline & Government & 65 & 2.8 \\
\hline & employed & & \\
\hline & Housewife & 550 & 23.7 \\
\hline \multirow[t]{3}{*}{ Ethnicity } & Oromo & 2,070 & 89.3 \\
\hline & Amhara & 242 & 10.4 \\
\hline & Other & 7 & 0.3 \\
\hline
\end{tabular}

Out of the 2,121 study participants who had heard about HIV/AIDS, 1,967 (92.7\%) scored above the mean in regard to the overall knowledge of HIV/AIDS. Crude and adjusted effects of selected covariates obtained from logistic regression are summarized in Table 3 for the overall knowledge about HIV/AIDS. Study participants who could read/ write $(\mathrm{AOR}=2.54,95 \% \mathrm{CI}: 1.15-5.61, P=0.021)$, 5-8th grade study participants (AOR $=2.32,95 \% \mathrm{CI}: 1.16-4.65$, $P=0.017$ ), and worked as a daily laborer ( $\mathrm{AOR}=0.40,95 \%$ CI: 0.17-0.91, $P=0.029)$ were significantly associated with comprehensive knowledge about HIV/AIDS (Table 3). 
Table 2 Study participants' knowledge about HIV/AIDS among households in six woredas of East Hararghe Zone, February to March $2014(n=2,319)$

\begin{tabular}{|c|c|c|c|}
\hline \multirow[t]{2}{*}{ Variable } & \multicolumn{3}{|c|}{ Respondent's residence } \\
\hline & Urban, n (\%) & Rural, n (\%) & Total, n (\%) \\
\hline \multicolumn{4}{|l|}{ Have you heard about } \\
\hline \multicolumn{4}{|l|}{ HIVIAIDS? } \\
\hline I. Yes & $333(98.8)^{*}$ & I,788 $(90.2)^{*}$ & $2,121(91.5)$ \\
\hline 2. No & $4(1.2)$ & $194(9.8)$ & $198(8.5)$ \\
\hline 3. Don't know & - & - & - \\
\hline \multicolumn{4}{|l|}{ From where did you } \\
\hline \multicolumn{4}{|l|}{ hear about HIVIAIDS? } \\
\hline I. Family members & $55(16.5)^{*}$ & $385(21.5)^{*}$ & $440(20.7)$ \\
\hline 2. Friends & $221(66.4)^{*}$ & $596(33.3)^{*}$ & $817(38.5)$ \\
\hline $\begin{array}{l}\text { 3. Mass media } \\
\text { (radio, TV, etc) }\end{array}$ & $45(13.5)$ & $303(16.9)$ & $348(16.4)$ \\
\hline \multicolumn{4}{|l|}{ 4. Health extension } \\
\hline workers (HEWs) & $179(53.7)^{*}$ & I,376 (77)* & I,555 (73.3) \\
\hline 5. Don't remember & - & - & - \\
\hline \multicolumn{4}{|l|}{ Is HIVIAIDS a } \\
\hline \multicolumn{4}{|l|}{ transmittable disease? } \\
\hline I. Yes & $330(99.1)$ & I,764 (98.7) & $2,094(98.7)$ \\
\hline 2. No & $3(0.9)$ & $24(1.3)$ & $27(1.3)$ \\
\hline 3. Don't know & - & - & - \\
\hline \multicolumn{4}{|l|}{ What is/are the main } \\
\hline \multicolumn{4}{|l|}{ route/s of transmission? } \\
\hline $\begin{array}{l}\text { I. Unsafe sexual } \\
\text { intercourse }\end{array}$ & $209(63.3)^{*}$ & I,408 (79.8)* & $\mathrm{I}, 617(77.2)$ \\
\hline $\begin{array}{l}\text { 2. Contaminated } \\
\text { needle/sharp } \\
\text { materials }\end{array}$ & $289(87.6)$ & I,524 (86.4) & $\mathrm{I}, 813(86.6)$ \\
\hline 3. Others & $6(1.8)$ & $32(1.8)$ & $38(1.8)$ \\
\hline 4. Do not know & $35(10.6)$ & $30(1.7)$ & $65(3.1)$ \\
\hline \multicolumn{4}{|l|}{ Is HIVIAIDS a } \\
\hline \multicolumn{4}{|l|}{ preventable disease? } \\
\hline I. Yes & $321(96.4)$ & I,748 (97.8) & $2,069(97.5)$ \\
\hline 2. No & $12(3.6)$ & $40(2.2)$ & $52(2.4)$ \\
\hline 3. Don't know & - & - & - \\
\hline \multicolumn{4}{|l|}{$\begin{array}{l}\text { What type of prevention } \\
\text { methods are you using? }\end{array}$} \\
\hline $\begin{array}{l}\text { I. Safe sexual } \\
\text { intercourse }\end{array}$ & $156(48.6)^{*}$ & I,396 (79.9)* & $\mathrm{I}, 552(75)$ \\
\hline $\begin{array}{l}\text { 2. By taking care } \\
\text { from contaminated } \\
\text { needle/sharp } \\
\text { materials }\end{array}$ & $273(85.1)$ & $\mathrm{I}, 442(82.5)$ & I,7I5 (82.9) \\
\hline \multicolumn{4}{|l|}{ 3. Using screened } \\
\hline blood for transfusion & $98(30.5)^{*}$ & $824(47.1)^{*}$ & $922(44.6)$ \\
\hline 4. Don't know & - & - & - \\
\hline \multicolumn{4}{|l|}{ Is HIVIAIDS cured with } \\
\hline \multicolumn{4}{|l|}{ effective treatment? } \\
\hline I. Yes & $33(9.9)$ & $132(7.4)$ & $165(7.8)$ \\
\hline 2. No & $300(90.1)$ & $1,656(92.6)$ & $1,956(92.2)$ \\
\hline 3. Don't know & - & - & - \\
\hline \multicolumn{4}{|l|}{$\begin{array}{l}\text { Did the HEWs teach you } \\
\text { about HIVIAIDS? }\end{array}$} \\
\hline I. Yes & $165(49.6)^{*}$ & I,554 (86.9)* & I,7। $9(81.1)$ \\
\hline 2. No & $168(50.4)$ & $234(13.1)$ & $402(18.9)$ \\
\hline 3. Don't remember & - & - & - \\
\hline
\end{tabular}

Note: *Statistically significant difference.

\section{Knowledge and practice of study participants regarding malaria}

Among the 2,319 study participants involved in the study, the majority $(93.7 \%)$ of the study participants reported that they had heard about malaria before the study period. However, the proportion of urban study participants who had heard about malaria was significantly higher than that of the rural study participants $\left(97 \%\right.$ vs $93.1, \chi^{2}=7.5495$, $P=0.006$ ) (Table 4).

Out of the 2,172 study participants, 934 (43\%) scored above the mean in regard to the overall knowledge of malaria. Rural residents (AOR $=0.27,95 \%$ CI: $0.17-0.44, P<0.005$ ), $>45$ years of age $(\mathrm{AOR}=1.44,95 \% \mathrm{CI}: 1.04-1.99, P=0.030)$, single marital status (AOR $=3.81,95 \% \mathrm{CI}: 1.97-7.37$, $P<0.005)$, educational status of the female who could read and write $(\mathrm{AOR}=1.95,95 \% \mathrm{CI}: 1.16-3.27, P=0.012)$, occupational status of the female (daily laborer $[\mathrm{AOR}=0.58$, 95\% CI: $0.37-0.92, P=0.020$ ], government employee [AOR $=0.53,95 \%$ CI: $0.14-0.80, P=0.014]$ ), and frequency of the visits done by the HEWs (AOR $=0.47,95 \%$ CI: $0.31-0.70$, $P<0.005)$ were significantly associated with comprehensive knowledge about malaria (Table 5).

\section{Discussion}

The results of this community-based cross-sectional study showed that the overall knowledge of the respondents about HIV was high. A comparable report found in Gambella town, Western Ethiopia, revealed that $\sim 96 \%$ of the interviewed population reported to have heard about HIV/AIDS. The study reported unprotected sex (79.7\%) and unsafe blood transfusion (64.2\%) as common ways of HIV transmission. ${ }^{8}$ But in a health facility-based study in Harar, $48.7 \%$ of the respondents scored above the mean in regard to overall knowledge about HIV. ${ }^{9}$ Another community-based study in the People's Republic of China indicated a significant level of lack of knowledge about HIV. ${ }^{10}$ High overall knowledge in the present study area might be due to improved access to primary health care units, frequent visits to households by HEWs, and success of HEP in disseminating health information for the community members about disease prevention. Creation of high awareness about HIV/AIDS in the community at large is helpful to reduce morbidity and mortality from HIV/AIDS, tuberculosis, and malaria through development of community skills and knowledge.

In the present study, the overall knowledge about malaria was low among the study participants. This result is supported by another study conducted in south-western Nigeria, which reported that $37 \%$ of the households thought 
Table 3 Association of study participants sociodemographic characteristics with an overall knowledge about HIV/AIDS, among the households in six woredas of East Hararghe Zone, February to March 2014

\begin{tabular}{|c|c|c|c|c|c|}
\hline \multirow[t]{2}{*}{ Variable } & \multirow[t]{2}{*}{ Category } & \multicolumn{4}{|c|}{ Overall knowledge about HIVIAIDS } \\
\hline & & High, n (\%) & Low, n (\%) & COR $(95 \% \mathrm{Cl})$ & AOR $(95 \% \mathrm{Cl})$ \\
\hline \multirow[t]{2}{*}{ Residence } & Urban & $303(15.4)$ & $30(19.5)$ & $\mathrm{R}$ & \\
\hline & Rural & $\mathrm{I}, 664(84.6)$ & $124(80.5)$ & $1.33(0.87-2.02)$ & $0.98(0.49-1.96)$ \\
\hline \multirow[t]{3}{*}{ Age, years } & $18-30$ & $935(47.5)$ & $59(38.3)$ & $\mathrm{R}$ & \\
\hline & $31-45$ & $687(34.9)$ & $38(24.7)$ & $1.14(0.75-1.73)$ & $1.50(0.97-2.34)$ \\
\hline & $>45$ & $345(17.5)$ & $57(37)$ & $0.38(0.26-0.56)^{*}$ & $0.74(0.47-1.16)$ \\
\hline \multirow[t]{4}{*}{ Marital status } & Married & I,749 (89) & $121(78.6)$ & $\mathrm{R}$ & \\
\hline & Single & $83(4.2)$ & $13(8.4)$ & $0.44(0.24-0.82)^{*}$ & $0.63(0.32-1.25)$ \\
\hline & Divorced & $81(4.1)$ & $17(11)$ & $0.33(0.19-0.57)^{*}$ & $0.60(0.33-1.09)$ \\
\hline & Separated & $53(2.7)$ & $3(2)$ & $1.22(0.38-3.97)$ & $1.86(0.55-6.29)$ \\
\hline \multirow[t]{3}{*}{ Religion } & Christian & $256(13)$ & $30(19.5)$ & $\mathrm{R}$ & \\
\hline & Muslim & I,708 (86.8) & $123(79.9)$ & $1.63(1.07-2.48)$ & $0.93(0.35-2.42)$ \\
\hline & Other & $3(0.2)$ & $\mathrm{I}(0.6)$ & $0.35(0.03-3.49)$ & $0.36(0.03-4.49)$ \\
\hline \multirow[t]{3}{*}{ Ethnicity } & Oromo & $1,749(88.9)$ & $125(8 \mid .2)$ & $\mathrm{R}$ & \\
\hline & Amhara & $211(10.7)$ & $29(18.8)$ & $0.52(0.34-0.80)^{*}$ & $0.50(0.19-1.31)$ \\
\hline & Other & $7(0.4)$ & - & - & - \\
\hline \multirow[t]{7}{*}{ Educational status } & Illiterate & $1,355(68.9)$ & $122(79.2)$ & $\mathrm{R}$ & \\
\hline & Read/write & $132(6.7)$ & $8(5.2)$ & $1.48(0.7 \mathrm{I}-3.10)$ & $1.61(0.67-3.84)$ \\
\hline & Ist-4th Grade & $155(7.9)$ & $9(5.8)$ & $1.55(0.77-3.11)$ & $0.8 I(0.37-1.77)$ \\
\hline & 5th-8th Grade & $188(9.6)$ & $5(3.2)$ & $3.38(1.37-8.39)^{*}$ & $2.07(0.7 I-6.01)$ \\
\hline & 9th-10th Grade & $100(5.08)$ & $10(6.5)$ & $0.90(0.46-1.77)$ & $0.8 \mathrm{I}(0.3 \mathrm{I}-2.10)$ \\
\hline & IIth-12th Grade & $4(0.2)$ & - & - & - \\
\hline & $>12$ th Grade & $33(1.6)$ & - & - & - \\
\hline \multirow[t]{4}{*}{ Occupation } & Farmer & $1,207(61.4)$ & $119(77.3)$ & $\mathrm{R}$ & \\
\hline & Daily laborer & $186(9.5)$ & $24(15.6)$ & $0.76(0.48-1.22)$ & $0.92(0.43-1.98)$ \\
\hline & Government employee & $60(3.1)$ & $4(2.6)$ & $1.48(0.53-4.14)$ & $0.84(0.2 \mathrm{I}-3.34)$ \\
\hline & Housewife & $514(26.1)$ & $7(4.5)$ & $7.24(3.35-15-62)^{*}$ & $5.56(2.47-12.53)^{*}$ \\
\hline \multirow[t]{2}{*}{ Health facility } & Yes & $1,938(98.5)$ & $153(99.4)$ & $\mathrm{R}$ & \\
\hline & No & $29(1.5)$ & $\mathrm{I}(0.6)$ & $2.29(0.3 \mathrm{I}-16.92)$ & $2.76(0.34-22.43)$ \\
\hline \multirow[t]{2}{*}{ Visit by HEWs } & Yes & $1,815(92.3)$ & |4| (91.6) & $\mathrm{R}$ & \\
\hline & No & $152(7.7)$ & $13(8.4)$ & $0.91(0.50-1.64)$ & $0.54(0.28-1.02)$ \\
\hline
\end{tabular}

Note: *shows there is a statistically significant difference compared to the Reference on binary and multivariate logistic regression.

Abbreviations: $\mathrm{AOR}$, adjusted odds ratio; $\mathrm{COR}$, crude odds ratio; $\mathrm{Cl}$, confidence interval; $\mathrm{HEWs}$, health extension workers; $\mathrm{R}$, reference.

that intense sunshine was the cause of malaria, $2.1 \%$ cold weather, $1 \%$ flies, and $34.4 \%$ stress. ${ }^{11}$ A study in metropolitan Lagos, Nigeria, revealed that knowledge of the role of mosquitoes in malaria transmission (11.8\%) and cause of malaria $(9.6 \%)$ was observed to be low among the study population. ${ }^{12}$ A study in the low endemic setting of Shewa Robit Town, northeastern Ethiopia, revealed that some of the respondents $(>20 \%)$ mentioned lack of personal hygiene, exposure to cold weather, hunger, chewing maize stalk, body contact with a malaria patient, and flies as the causes of malaria. ${ }^{13}$ This result is incoherent with previous findings of other studies conducted among 630 households in Butajira, Ethiopia, which revealed fever, headaches, and chills and shivering were the most frequently mentioned symptoms of malaria reported by $89.7 \%, 87.5 \%$, and $81.3 \%$ of the study subjects, respectively; ${ }^{14}$ in northern Ghana revealed $79 \%$ of respondents attributed the mode of malaria transmission by mosquitoes,${ }^{15}$ in rural northwest Tanzania, 366 households (86.3\%) agreed with indoor residual spraying of insecticides $;{ }^{16}$ and in rural areas of Rajkot woreda, Gujarat, India, revealed that the respondents were found to have knowledge that malaria is a mosquito-borne disease. ${ }^{17}$ This might be due to an implementation gap observed in designed strategies to disseminate information regarding all components of knowledge about malaria.

In the present study, the majority ( $93.7 \%$ ) of respondents reported to have heard about malaria before the study period. This was consistent with other studies conducted in rural northwest Tanzania where 364/366 household heads had heard of malaria, ${ }^{16}$ in rural areas of Rajkot, Gujarat, India, ${ }^{17}$ and in a low endemic setting of Shewa Robit Town, northeastern Ethiopia ${ }^{13}$ showed that almost all the respondents had heard about malaria. The main source of information was HEWs which indicates the strength of HEP. 
Table 4 Study participants' knowledge about malaria among the households in six woredas of East Hararghe Zone, February to March $2014(n=2,172)$

\begin{tabular}{|c|c|c|c|}
\hline \multirow[t]{2}{*}{ Variable } & \multicolumn{3}{|c|}{ Respondent's residence } \\
\hline & Urban, n (\%) & Rural, n (\%) & Total, n (\%) \\
\hline \multicolumn{4}{|l|}{ Have you heard about } \\
\hline \multicolumn{4}{|l|}{ malaria? } \\
\hline I. Yes & $327(97)^{*}$ & I,845 (93.I)* & $2,172(93.7)$ \\
\hline 2. No & $10(3)$ & $137(6.9)$ & $147(6.3)$ \\
\hline \multicolumn{4}{|l|}{ From where did you } \\
\hline \multicolumn{4}{|l|}{ hear about malaria? } \\
\hline I. Family members & $34(10.4)^{*}$ & $355(19.2)^{*}$ & 389 (I7.9) \\
\hline 2. Friends & $191(58.4)^{*}$ & $474(25.7)^{*}$ & $665(30.6)$ \\
\hline $\begin{array}{l}\text { 3. Mass media } \\
\text { (radio, TV, etc) }\end{array}$ & $37(11.3)$ & $244(13.2)$ & $28 I(12.9)$ \\
\hline $\begin{array}{l}\text { 4. Health extension } \\
\text { workers (HEWs) }\end{array}$ & $164(50.1)^{*}$ & I,397 (75.7)* & I,56I (7I.9) \\
\hline 5. Others & $20(6.1)$ & $69(3.7)$ & $89(4.1)$ \\
\hline \multicolumn{4}{|l|}{$\begin{array}{l}\text { What are the major } \\
\text { symptoms of malaria? }\end{array}$} \\
\hline I. Fever & $266(81.3)$ & I,464 (79.3) & I,730 (79.6) \\
\hline 2. Severe headache & $78(23.8)^{*}$ & $749(40.6)^{*}$ & $827(38.1)$ \\
\hline 3. Chills & $117(35.8)^{*}$ & $938(50.8) *$ & I,055 (48.6) \\
\hline 4. Joint pain & $23(7)^{*}$ & $235(12.7)^{*}$ & $258(11.9)$ \\
\hline 5. Lack of appetite & $105(32.1)$ & $629(34.1)$ & $734(33.8)$ \\
\hline \multicolumn{4}{|l|}{ Is malaria a } \\
\hline \multicolumn{4}{|l|}{ communicable disease? } \\
\hline I. Yes & $277(84.7)^{*}$ & I,460 (79. I)* & $\mathrm{I}, 737(80)$ \\
\hline 2. No & $50(15.3)$ & $385(20.9)$ & $435(20)$ \\
\hline \multicolumn{4}{|l|}{$\begin{array}{l}\text { What is/are the main } \\
\text { route/s of transmission? }\end{array}$} \\
\hline I. Mosquito bite & $269(97.1)$ & I,380 (94.5) & I,649 (95) \\
\hline $\begin{array}{l}\text { 2. Drinking } \\
\text { contaminated water }\end{array}$ & $9(3.2)^{*}$ & $452(3 \mathrm{I})^{*}$ & $46 I(26.5)$ \\
\hline $\begin{array}{l}\text { 3. Direct contact } \\
\text { with sick person }\end{array}$ & $9(3.2)^{*}$ & $328(22.5)^{*}$ & $337(19.4)$ \\
\hline $\begin{array}{l}\text { 4. Eating/drinking } \\
\text { together }\end{array}$ & $3(I . I)^{*}$ & $288(19.7)^{*}$ & $291(16.7)$ \\
\hline 5. Others & $21(7.6)$ & $18(1.2)$ & $39(2.2)$ \\
\hline \multicolumn{4}{|l|}{ Is malaria a preventable } \\
\hline \multicolumn{4}{|l|}{ disease? } \\
\hline I. Yes & $323(98.8)^{*}$ & I,766 (95.7)* & $2,089(96.2)$ \\
\hline 2. No & $4(1.2)$ & $79(4.3)$ & $83(3.8)$ \\
\hline \multicolumn{4}{|l|}{ Does your household have } \\
\hline \multicolumn{4}{|l|}{ Insecticides Treated Nets? } \\
\hline I. Yes & |7| (50.7)* & $766(38.6)^{*}$ & $937(40.4)$ \\
\hline 2. No & $166(49.3)$ & $\mathrm{I}, 216(61.4)$ & I,382 (59.6) \\
\hline \multicolumn{4}{|l|}{ Is malaria a fatal/severe } \\
\hline \multicolumn{4}{|l|}{ disease? } \\
\hline I. Yes & $240(73.4)$ & I,415 (76.7) & I,655 (76.2) \\
\hline 2. No & $87(26.6)$ & $430(23.3)$ & $517(23.8)$ \\
\hline \multicolumn{4}{|l|}{ Is malaria curable with } \\
\hline \multicolumn{4}{|l|}{ effective treatment? } \\
\hline I. Yes & $315(96.3)$ & I,717 (93.1) & $2,032(93.6)$ \\
\hline 2. No & $12(3.7)$ & $128(6.9)$ & $140(6.4)$ \\
\hline \multicolumn{4}{|l|}{ Did the HEWs teach } \\
\hline \multicolumn{4}{|l|}{ you about malaria? } \\
\hline I. Yes & I8I (53.7) & I,59I (80.3) & I,772 (76.4) \\
\hline 2. No & $156(46.3)$ & $391(19.7)$ & $547(23.6)$ \\
\hline
\end{tabular}

Note: *Statistically significant difference.
In the present study, the majority ( $80 \%$ ) of study participants mentioned malaria as being a communicable disease. However, a considerable number $(20 \%)$ of the study participants replied that malaria can be transmitted by drinking contaminated water. Thus, the knowledge level of respondents about the mode of malaria transmission is not satisfactory when compared to the findings of other previous studies reported across Africa, such as in the Kishe settlement area, South West Ethiopia, ${ }^{18}$ Baringo Woreda, Kenya, ${ }^{19}$ and a low endemic setting of Shewa Robit Town, northeastern Ethiopia. ${ }^{13}$ This may be attributable to not addressing the misconception of the community members concerning correct mode of transmission about malaria. So, a misconception about malaria transmission still exists. Increasing the knowledge about malaria transmission and benefits of using the available effective, preventive, and control measures by the individual households and the community could contribute greatly to the overall reduction of the malaria burden.

The present study has demonstrated that respondents had a good knowledge about malaria signs and symptoms. The majority of the respondents mentioned fever as the most common symptom of malaria, which is in agreement with observations from other similar studies in a rural community in Ethiopia, ${ }^{14}$ and rural areas of Rajkot, Gujarat, India. ${ }^{17}$ This high level of awareness of the clinical features of malaria might be due to the frequent visits to households by HEWs.

\section{Limitations}

This cross-sectional survey may be subjected to recall bias. However, its effect was minimized by reducing the recall period of intervention method use and onset of malaria-related morbidity to 2 weeks prior to the data collection date. It would also be more appropriate to use analytical approaches to assess the roles of HEWs on community knowledge levels and complementing the study with a qualitative data collection approach.

\section{Conclusion and recommendation}

HEWs monthly number of regular visits to households was high.

The present study also assessed the overall study participants' knowledge toward the risk of HIV/AIDS and associated factors using a community-based cross-sectional study. The results indicate that the majority (92.7\%) of study participants have a good overall knowledge about HIV/AIDS. Despite the high level of knowledge, there is still some misconception and speculation about HIV treatment. Thus, consideration needs to be given to improve the absence of effective treatment. Rather, the community needs to be more aware about the treatment role which significantly improves the possibility of living with HIV. 
Table 5 Association of study participants' sociodemographic characteristics with overall knowledge about malaria among households in six woredas of East Hararghe Zone, February to March 2014

\begin{tabular}{|c|c|c|c|c|c|}
\hline \multirow[t]{2}{*}{ Variable } & \multirow[t]{2}{*}{ Category } & \multicolumn{4}{|c|}{ Comprehensive knowledge about malaria } \\
\hline & & High, n (\%) & Low, n (\%) & COR $(95 \% \mathrm{Cl})$ & AOR $(95 \% \mathrm{Cl})$ \\
\hline \multirow[t]{2}{*}{ Residence } & Urban & $92(9.8)$ & 235 (19) & $\mathrm{R}$ & \\
\hline & Rural & $842(90.2)$ & $\mathrm{I}, 003(8 \mathrm{I})$ & $0.47(0.36-0.60)^{*}$ & $0.27(0.17-0.44)^{*}$ \\
\hline \multirow[t]{3}{*}{ Age, years } & $18-30$ & $524(56.1)$ & $453(36.6)$ & $\mathrm{R}$ & \\
\hline & $31-45$ & $289(30.9$ & $48 I(38.8)$ & $1.92(1.59-2.33)^{*}$ & $1.26(0.98-1.6 I)$ \\
\hline & $>45$ & $12 \mid(13)$ & $304(24.6)$ & $2.91(2.27-3.71)^{*}$ & $1.44(1.04-1.99)^{*}$ \\
\hline \multirow[t]{4}{*}{ Marital status } & Married & $869(93.1)$ & $\mathrm{I}, 037(83.8)$ & $\mathrm{R}$ & \\
\hline & Single & $21(2.3)$ & $88(7.1)$ & $3.5 \mathrm{I}(2.16-5.70)^{*}$ & $3.81(1.97-7.37)^{*}$ \\
\hline & Divorced & $19(2)$ & $78(6.3)$ & $3.44(2.07-5.72)^{*}$ & $1.58(0.90-2.78)$ \\
\hline & Separated & $24(2.6)$ & $35(2.8)$ & $1.22(0.72-2.07)$ & $0.57(0.31-1.06)$ \\
\hline \multirow[t]{3}{*}{ Religion } & Christian & 108 (II.6) & $173(14)$ & $\mathrm{R}$ & \\
\hline & Muslim & $823(88.1)$ & I,064 (85.9) & $0.8 \mathrm{I}(0.62-1.04)$ & $1.90(0.99-3.65)$ \\
\hline & Other & $3(0.3)$ & $\mathrm{I}(0 . \mathrm{I})$ & $0.21(0.02-2.03)$ & $0.19(0.12-2.71)$ \\
\hline \multirow[t]{3}{*}{ Ethnicity } & Oromo & $852(9 \mid .2)$ & $\mathrm{I}, 079(87.1)$ & $\mathrm{R}$ & \\
\hline & Amhara & $76(8.1)$ & $158(12.8)$ & $1.64(1.23-2.19)^{*}$ & $2.43(1.22-4.84)^{*}$ \\
\hline & Other & $6(0.7)$ & $\mathrm{I}(0.1)$ & $0.13(0.01-1.09)$ & $0.2 I(0.02-2.7 I)$ \\
\hline \multirow[t]{7}{*}{ Educational status } & Illiterate & $579(62)$ & 961 (77.6) & $\mathrm{R}$ & \\
\hline & Read / write & $28(3)$ & III (9) & $2.39(1.56-3.66)^{*}$ & $1.95(1.16-3.27)^{*}$ \\
\hline & Ist-4th Grade & $109(8.7)$ & $52(4.2)$ & $0.29(0.20-0.4 \mathrm{I})^{*}$ & $0.76(0.47-1.22)$ \\
\hline & 5th-8th Grade & 137 (II.7) & $50(4)$ & $0.22(0.16-0.31)^{*}$ & $0.69(0.40-1.16)$ \\
\hline & 9th-10th Grade & $64(6.8)$ & $44(3.6)$ & $0.4 \mathrm{I}(0.29-0.62)^{*}$ & $0.98(0.50-1.93)$ \\
\hline & IIth-12th Grade & $2(0.2)$ & $2(0.2)$ & $0.60(0.08-4.29)$ & $2.33(0.18-30.64)$ \\
\hline & $>12$ th Grade & $15(1.6)$ & $18(1.4)$ & $0.72(0.39-1.45)$ & $2.09(0.68-6.4 I)$ \\
\hline \multirow[t]{4}{*}{ Occupation } & Farmer & $403(43.2)$ & $\mathrm{I}, 0 \mathrm{II}(8 \mathrm{I} .7)$ & $\mathrm{R}$ & \\
\hline & Daily laborer & $55(5.9)$ & $160(12.9)$ & $1.16(0.83-1.61)$ & $0.58(0.37-0.92)^{*}$ \\
\hline & Government employee & $31(3.3)$ & $32(2.6)$ & $0.4 \mathrm{I}(0.25-0.68)^{*}$ & $0.33(0.14-0.80)^{*}$ \\
\hline & Housewife & $445(47.6)$ & $35(2.8)$ & $0.03(0.02-0.05)^{*}$ & $0.04(0.03-0.06)^{*}$ \\
\hline \multirow[t]{3}{*}{ Presence of health facility } & Yes & $923(98.8)$ & $\mathrm{I}, 2 \mathrm{II}(97.8)$ & $\mathrm{R}$ & \\
\hline & No & $10(1.1)$ & $27(2.2)$ & $1.06(0.99-4.27)$ & $1.36(0.29-5.76)$ \\
\hline & Not sure & $I(0.1)$ & - & & \\
\hline \multirow[t]{2}{*}{ Frequent by the HEWs } & Yes & $84 \mid(90)$ & $\mathrm{I}, 16 \mathrm{I}(93.8)$ & $\mathrm{R}$ & \\
\hline & No & $93(10)$ & $77(6.2)$ & $0.60(0.44-0.82)^{*}$ & $0.47(0.3 \mathrm{I}-0.70)^{*}$ \\
\hline
\end{tabular}

Note: *shows there is a statistically significant difference compared to the Reference on binary and multivariate logistic regression.

Abbreviations: AOR, adjusted odds ratio; COR, crude odds ratio; $\mathrm{Cl}$, confidence interval; $\mathrm{HEWs}$, health extension workers; $\mathrm{R}$, reference.

The study subjects' awareness regarding symptoms and preventive measures of malaria was high. Despite the HEWs playing a scientific role on upgrading the community's knowledge on disease prevention, the findings of this study revealed that study participants had an unsatisfactory overall knowledge about malaria. A misconception about malaria transmission still exists. Furthermore, use of other preventive measures was low. Therefore, efforts are needed to strengthen the existing overall knowledge of the study participants about malaria, especially on the mode of disease transmission, proper handling, and effective use of malaria bed nets.

\section{Acknowledgments}

The authors would like to acknowledge the study participants. The study was financially supported by Haramaya University, Office of Research Affairs.

\section{Author contributions}

AS designed the study, participated in data collection, analysis, and drafted the manuscript. KU and TG participated in study design, analysis, write-up, and critically revised the manuscript. All authors read and approved the final manuscript. AS is the guarantor of the paper.

\section{Disclosure}

The authors report no conflicts of interest in this work.

\section{References}

1. Idele P, Gillespie A, Porth T, et al. Epidemiology of HIV and AIDS among adolescents: current status, inequities, and data gaps. J Acquir Immune Defic Syndr. 2014;66:S144-S153.

2. World Health Organization. Fact Sheet:2015 World Malaria Report. 2016. Available at http://http://www.who.int/mediacentre/factsheets/ fs094/en/ Accessed December 9,2015]

3. Banteyerga H. Ethiopia's health extension program: improving health through community involvement. MEDICC Rev. 2011;13(3):46-49. 
4. Sebhatu A. The implementation of Ethiopia's Health Extension Program: An overview; 2008. Available from: http://www.ppdafrica.org/index. php/en/publications/documents/139-ethiopiahep. Accessed February 10, 2012.

5. Yimer S, Holm-Hansen C, Yimaldu T, Bjune G. Health care seeking among pulmonary tuberculosis suspects and patients in rural Ethiopia: a community-based study. BMC Public Health. 2009;9(1):454.

6. Mesfin MM, Tasew TW, Tareke IG, Mulugeta GW, Richard MJ. Community knowledge, attitudes and practices on pulmonary tuberculosis and their choice of treatment supervisor in Tigray, northern Ethiopia. Ethiop J Health Dev. 2005;19(I):21.

7. Abebe G, Deribew A, Apers L, et al. Knowledge, health seeking behavior and perceived stigma towards tuberculosis among tuberculosis suspects in a rural community in southwest Ethiopia. PLoS one. 2010;5(10):e13339.

8. Negash Y, Gebre B, Benti D, Bejiga M. A community based study on knowledge, attitude and practice (KAP) on HIV/AIDS in Gambella town, Western Ethiopia. Ethiop J Health Dev. 2004;17(3):205-213.

9. Seyoum A, Legesse M. Knowledge of tuberculosis (TB) and human immunodeficiency virus (HIV) and perception about provider initiated HIV testing and counselling among TB patients attending health facilities in Harar town, Eastern Ethiopia. BMC Public Health. 2013;13(1):124.

10. Ma W, Detels R, Feng Y, et al. Acceptance of and barriers to voluntary HIV counselling and testing among adults in Guizhou province, China. AIDS (London, England). 2007;21(Suppl 8):S129.

11. Adedotun A, Morenikeji O, Odaibo A. Knowledge, attitudes and practices about malaria in an urban community in south-western Nigeria. J Vector Borne Dis. 2010;47(3):155-159.
12. Iriemenam N, Dosunmu A, Oyibo W, Fagbenro-Beyioku A. Knowledge, attitude, perception of malaria and evaluation of malaria parasitaemia among pregnant women attending antenatal care clinic in metropolitan Lagos, Nigeria. J Vector Borne Dis. 2011;48(1): $12-17$.

13. Abate A, Degarege A, Erko B. Community knowledge, attitude and practice about malaria in a low endemic setting of Shewa Robit Town, northeastern Ethiopia. BMC Public Health. 2013;13(1):312.

14. Deressa W, Ali A, Enquoselassie F. Knowledge, attitude and practice about malaria, the mosquito and antimalarial drugs in a rural community. Ethiop J Health Dev. 2004;17(2):99-104.

15. Adongo PB, Kirkwood B, Kendall C. How local community knowledge about malaria affects insecticide-treated net use in northern Ghana. Trop Med Int Health. 2005;10(4):366-378.

16. Mazigo HD, Obasy E, Mauka W, et al. Knowledge, attitudes, and practices about malaria and its control in rural northwest Tanzania. Malar Res Treat. 2010;2010:794261.

17. Chovatiya S. Studies on the Mosquitoes in the Rural Areas Around Rajkot City [dissertation]. Rajkot: Saurashtra University; 2010.

18. Adera TD. Beliefs and traditional treatment of malaria in Kishe settlement area, southwest Ethiopia. Ethiop Med J. 2003;41(1):25-34.

19. Munguti K. Community perceptions and treatment seeking for malaria in Baringo district, Kenya: implications for disease control. East Afr Med J. 1998;75(12):687-691.

20. Roca-Feltrer A, Lalloo DG, Phiri K, Terlouw DJ. Rolling Malaria Indicator Surveys (rMIS): A Potential District-Level Malaria Monitoring and Evaluation (M\&E) tool for program managers. Am JTrop Med Hyg. 2012; 86(1):96-98.
Risk Management and Healthcare Policy

\section{Publish your work in this journal}

Risk Management and Healthcare Policy is an international, peer-reviewed, open access journal focusing on all aspects of public health, policy, and preventative measures to promote good health and improve morbidity and mortality in the population. The journal welcomes submitted papers covering original research, basic science, clinical and epidemiological

\section{Dovepress}

studies, reviews and evaluations, guidelines, expert opinion and commentary, case reports and extended reports. The manuscript management system is completely online and includes a very quick and fair peerreview system, which is all easy to use. Visit http://www.dovepress.com/ testimonials.php to read real quotes from published authors. 